\title{
Hair care formulations containing argan oil: development, stability and texture profile
}

\author{
Formulações para os cuidados do cabelo contendo óleo de argan: desenvolvimento, \\ estabilidade e perfil de textura
}

\author{
Stefânia Duz Delsin, Patricia M.B.G. Maia Campos \\ Faculdade de Ciências Farmacêuticas de Ribeirão Preto - Universidadede São Paulo \\ Av. do Café S/N, Monte Alegre, 14040-903, Ribeirão Preto, SP, Brasil \\ Email: pmcampos@usp.br
}

\begin{abstract}
The aim of this study was to develop hair care cosmetic formulations containing argan oil to evaluate the stability and texture profile of these formulations.

Shampoos, conditioners and leave-in formulations were developed with or without (vehicle) argan oil in concentrations of $0.1,2.0$ and $2.0 \%(\mathrm{w} / \mathrm{w})$ respectively.

The formulations were stored at room temperature $\left(25^{\circ} \mathrm{C}\right), 37^{\circ} \mathrm{C}$ and $45^{\circ} \mathrm{C}$ for a period of 28 days and submitted to spreadability and texture tests using the Texture Analyser. For this purpose, work of shear and consistency parameters were determined. The results have shown that all formulations were stable and the argan oil-based formulations had a better spreadability when compared with the vehicle. This is a desirable effect, once cosmetic formulations which presents a lower values of work of shear are better accepted by cosmetic sensory panels. In addition, no difference was found between conditioners with or without argan oil in terms of texture profile, and leave-informulation with argan oil showed an increased consistency when compared with the vehicle. Finally, formulations with argan oil showed better the texture profile, therefore, it is a potential ingredient for use in hair care formulations.
\end{abstract}

Keywords: Argan Oil, hair care formulations; Stability, Texture profile

\section{Resumo}

O objetivo deste estudo foi desenvolver e avaliar a estabilidade e textura de formulações cosméticas para os cuidados dos cabelos contendo óleo de argan.

Formulações de shampoos, condicionadores e leave on foram desenvolvidas com ou sem (veículo) óleo de argan nas concentrações de $0,1,2,0$ e $2,0 \%$ (a/a), respectivamente.

As formulações foram armazenadas à temperatura ambiente $\left(25^{\circ} \mathrm{C}\right), 37^{\circ} \mathrm{C}$ e $45^{\circ} \mathrm{C}$, por 28 dias e submetidas à testes de espalhabilidade e de textura utilizando um texturômetro. Foram avaliados os parâmetros de "Work of Shear" e consistência. Os resultados mostraram que as formulações foram estáveis e as formulações com óleo de argan mostraram melhor espalhabilidade quando comparada com o veículo. Este é um efeito desejável pois formulações cosméticas que apresentam baixos valores de "Work of Shear" são mais bem aceitas por painéis sensoriais. Além disso, não houve diferença entre os condicionadores, com ou sem óleo de argan, em termos de perfil de textura e a formulação leave on contendo óleo de argan mostrou um aumento da consistência em relação ao o veículo. Por fim, as formulações contendo o óleo de argan mostraram um melhor perfil de textura, e portanto, este é um potencial ingrediente para utilização em formulações para os cuidados dos cabelos.

Palavras-chave: Óleo de Argan, Formulações para os cuidados dos cabelos; Estabilidade, Perfil de textura 


\section{Introduction}

Argan oil is an oil produced from the kernels of the argan tree, endemic to Morocco, and is valued for its nourishing action. It is a natural product resulting from pressure extraction of almonds and dried fruits of argan, a tree available only in the biosphere reserve territory in southern Morocco.

Argan oil is exceptionally rich in tocopherols (vitamin E), phenols and phenolic acid, carotenes, squalene and essential fatty acids, including linoleic acid (omega 6), $\gamma$ tocopherols (biological antioxidants), sterols (especially Schotteno $1(44-49 \%)$ ), and five terpene alcohols, including Lupeol (7.1\%) ${ }^{1}$.

Argan oil was first used as a cosmetic ingredient in southern Morocco, where women utilized it for body and hair care. Due to its high content of vitamin E, this oil moisturizes and acts against dryness and ageing. In addition, argan oil has nourishing and revitalizing properties, strengthening and giving natural shine and softness to hair ${ }^{2}$.

Considering the importance of the application of vegetable oils in cosmetics for hair care, and due to its properties, argan oil has been highlighted for its rich composition, which can provide antioxidant activity, moisturizing and protective effects when applied in hair care products. Thus, argan oil stands out as a potential ingredient in the development of cosmetic products for hair care.

During the development of cosmetic formulations, it is important to analyse if the mechanical and physical properties of the formulations are within criteria for quality and stability, ensuring that the consumer will have a safe and efficient finished product with a guarantee of quality.

It is also important to evaluate the stability and texture of cosmetic formulations as such analyses provide information about the behaviour of these formulations over time, according to the influence of external factors such as temperature, humidity and light. In this way, it is possible to determine the shelf life of various products, as stability testing (accelerated and long-term) simulate the shelf storage conditions of these cosmetic formulations under study ${ }^{3}$.

The testing of mechanical physical properties (texture) has been increasingly employed to characterize formulations in cosmetic, pharmaceutical and food industries. The tests are conducted using a specialized piece of equipment, a TA.XTplus Texture Analyser (Stable Micro Systems Surrey, UK), which contains specific software for acquisition and processing of data. This texturometer allows the evaluation of various parameters

\section{Introdução}

O óleo de argan é um óleo produzido a partir do miolo da árvore de argan, endêmica em Marrocos, que é valorizado por sua ação nutritiva e é um produto natural resultante da pressão das amêndoas extraídas e dos frutos secos de argan, uma árvore disponível apenas no território de reserva da biosfera no sul de Marrocos.

Esse ativo é excepcionalmente rico em tocoferóis (vitamina E), fenóis e ácido fenólico, carotenos, esqualeno e ácidos graxos essenciais (óleo de argan contém altos níveis de ácidos graxos essenciais, incluindo ácido linoléico (ômega 6), $\gamma$ tocoferóis (antioxidantes biológicos), esteróis (especialmente Schotteno L (44 - 49\%) e ainda, cinco outros álcoois terpênicos, incluindo o Lupeol $(7,1 \%)^{1}$.

O óleo de argan era utilizado como cosmético no sul do Marrocos, onde as mulheres faziam uso com a finalidade de cuidar do corpo e dos cabelos. Devido ao seu alto teor de vitamina E, este ativo hidrata e atua contra o ressecamento e envelhecimento. Além disso, o óleo de argan nutre e revitaliza, fortalece e dá brilho natural e suavidade para os cabelos ${ }^{2}$.

Considerando a importância da aplicação de óleos vegetais em produtos cosméticos para o cuidado do cabelo, devido às suas propriedades, o óleo de argan tem-se destacado devido à sua rica composição, podendo fornecer atividade antioxidante, hidratante e efeitos protetores quando aplicado em produtos para os cabelos. Assim, o óleo de argan destaca-se como um potencial ingrediente para o desenvolvimento de produtos para os cuidados dos cabelos.

Durante o desenvolvimento de formulações cosméticas, é importante analisar se parâmetros como as propriedades mecânicas e físicas estão dentro dos critérios de estabilidade e qualidade assegurando que o consumidor tenha acesso ao produto acabado seguro e eficiente, garantindo sua qualidade.

Também é importante avaliar a estabilidade e textura de formulações cosméticas devido ao fato de que tal análise proporciona informações sobre o comportamento destas formulações ao longo do tempo, de acordo com a influência de fatores externos, como a temperatura, umidade e luz. Desta forma, é possível determinar o prazo de validade de vários produtos, através de ensaios de estabilidade (acelerada e a longo prazo) simulando as condições de prateleira destas formulações cosméticas sob estudo ${ }^{3}$.

A análise das propriedades físico mecânicas (textura) vem sendo cada vez mais empregada para caracterização de formulações em indústrias cosméticas, farmacêuticas e alimentícias. Os testes são realizados 
such as hardness, consistency, viscosity index, among others. This device is promising because it provides a comprehensive analysis of the formulations under study in a quick and effective way ${ }^{4}$.

\section{Material and Methods}

\section{Formulations studied}

Shampoos, conditioners and leave-ion formulations containing stable ingredients and with hydration properties were developed were developed and added, or not, with argan oil in concentrations of $0.1,2.0$ and $2.0 \%(\mathrm{w} / \mathrm{w})$ respectively.

\section{Stability and texture profile}

The developed hair care formulations were stored at room temperature $\left(25^{\circ} \mathrm{C}\right)$ and, submitted to heat stress ${ }^{5}$, $37^{\circ} \mathrm{C}$ and $45^{\circ} \mathrm{C}$, for a 28 -day period. After that time, they were submitted to spreadability and texture tests using the TA.XTplus Texture Analyser. Work of shear and consistency parameters of the formulations under study were determined. Work of shear corresponds to the work required for spreading the formulation on a surface and consistency evaluates the viscosity of a formulation $^{4}$.

\section{Spreadability Analysis}

For spreadability analysis, again the TA.XTplus Texture Analyser was used. Before commencing the analyses, the weight and the height of the probe used in the test were calibrated, providing an effective standardization to reduce possible experimental errors. The spreadability test consists of two probes (male and female) arranged at an angle of $90^{\circ}$ relative to the base unit. The formulations were placed in the female probe, and to avoid the formation of air bubbles, were packed into the container and excess formulation removed with a spatula. Thus assembled, the female probe containing the formulation was placed on the base support, which is aligned with the male cone containing the analysis probe. The samples were analysed in triplicate by a penetration test, by determining the parameter "Work of Shear" with distance of $25 \mathrm{~mm}$ at a speed of $20 \mathrm{~mm}$ / sec using an acrylic cone $\mathrm{e}^{6,7}$. utilizando-se o equipamento denominado texturômetro (Stable Micro Systems) o qual contém um software específico para aquisição e tratamento de dados (TA. XTplus Texture Analyser, Surrey, UK). O texturômetro permite avaliar diversos parâmetros tais como dureza, consistência, índice de viscosidade, dentre outros, ou seja, esse aparelho é promissor pois fornece uma ampla análise das formulações em estudo de maneira rápida e eficaz ${ }^{4}$.

\section{Materiais e Métodos}

\section{Desenvolvimento das formulações}

Foram desenvolvidas formulações base de shampoos, condicionadores e loções, com ingredientes estáveis e propriedades hidratantes para os cuidados dos cabelos, as quais foram acrescidas do óleo de argan nas concentrações de $0,1 \% ; 2 \%$ e $2 \%$ (a/a) respectivamente.

\section{Estabilidade e perfil textura}

As formulações desenvolvidas para os cuidados do cabelo foram armazenadas à temperatura ambiente $\left(25^{\circ} \mathrm{C}\right)$ e, submetidas ao estresse térmico ${ }^{5}, 37^{\circ} \mathrm{C} \mathrm{e} 45^{\circ} \mathrm{C}$ durante um período de 28 dias. Depois disso, foram submetidas aos testes de espalhabilidade e textura utilizando um texturômetro. Para isso, foram determinados os parâmetros de "Work of Shear" e de "Consistência" das formulações em estudo. O parâmetro "Work of Shear" corresponde ao trabalho necessário para espalhar a formulação sobre uma superfície e, a "Consistência" permite avaliar a viscosidade de uma formulação ${ }^{4}$.

\section{Análise de Espalhabilidade}

Para a análise da espalhabilidade foi utilizado um texturômetro (Stable Micro Systems) que contém um software específico para aquisição e tratamento dos dados obtidos (TA.XTplus Texture Analyser). Antes de se iniciar as análises, o peso e a altura da sonda utilizada no teste foram calibrados para que houvesse uma padronização eficaz minimizando possíveis erros experimentais. $\mathrm{O}$ teste de espalhabilidade consiste em dois probes (macho e fêmea) dispostos num ângulo igual a $90^{\circ}$ (em relação à base do aparelho). As formulações foram colocadas no probe fêmea, e para evitar a formação de bolhas de ar, as mesmas foram compactadas dentro do recipiente, e o excesso de formulação foi removido com uma espátula. Assim, o probe fêmea, contendo a formulação, foi colocado no suporte da base, sendo este alinhado com o cone macho, que contém a sonda de análise. As análises foram efetuadas em triplicata por teste de penetração, através da determinação do parâmetro "Work of Shear" com distância percorrida de $25 \mathrm{~mm}$, numa velocidade de $20 \mathrm{~mm} / \mathrm{s}$ utilizando cone acrílico em analisador de textura TA.XTplus (Stable Micro Systems) ${ }^{6,7}$. 


\section{Texture analysis - Extrusion (Back Extrusion)}

For texture analysis, a probe back extrusion was used, with a $25 \mathrm{~mm}$ compression disk. The samples were transferred to the container, filling up to $75 \%$ of its volume, and allowed to come to room temperature. The extrusion disc was positioned centrally above the vessel containing the sample.

The compression speed was $20 \mathrm{~mm} / \mathrm{s}$ at a distance of $30 \mathrm{~mm}$. The tests were conducted in triplicate, and with each sample exchange the disc and the container were cleaned and dried.

The cylinder starts descending towards the sample, and when the lower surface of the disc is in contact with the sample, it penetrates $30 \mathrm{~mm}$ into the sample surface. The sample undergoes extrusion between the walls of the container and the disc. After this point is reached (maximum force), the probe returns to the initial position $^{8}$.
Análise de Textura - Extrusão (Back Extrusion)

Para a análise de textura, foi utilizado o probe back extrusion, com um disco de compressão de $25 \mathrm{~mm}$. As amostras foram transferidas para o container até o preenchimento de $75 \%$ de seu volume e analisadas em temperatura ambiente. O disco de extrusão foi posicionado de forma central acima do recipiente contendo a amostra.

A velocidade de compressão foi de $20 \mathrm{~mm} / \mathrm{s}$ em uma distância de $30 \mathrm{~mm}$. Os testes foram realizados em triplicata, sendo que a cada troca de amostra, o disco e o container foram limpos e secos.

$\mathrm{O}$ cilindro inicia a descida em direção à amostra, e quando a superfície inferior do disco está em contato com a amostra, ele inicia a penetração em $30 \mathrm{~mm}$. A amostra sofre extrusão entre as paredes do container e do disco. Depois deste ponto (força máxima), o probe retorna à posição inicial ${ }^{8}$.

According to Figure 3 (A), for the consistency test, there were no significant differences in this parameter for the formulations FCA and FCV when we compared both of them. However, according to the viscosity index test (Figure 3B), there was a significant difference for this parameter when comparing the two formulations studied.

Figure 3 shows that the viscosity index of the formulation FCA was significantly lower when compared to the formulation FCV.

\section{Resultados}

\section{Perfil da Textura - Espalhabilidade}

As figuras 1 (A) e 2 (A, B e C) mostram o comportamento das formulações estudadas (shampoos) quando analisadas - utilizando o teste de espalhabilidade - acrescidas (FSA) ou não (veículo - FSV) de óleo de argan, nas diferentes temperaturas $\left(\operatorname{Tamb}\left(25^{\circ} \mathrm{C}\right), \mathrm{T} 37^{\circ} \mathrm{C}\right.$ e $\mathrm{T} 45^{\circ} \mathrm{C}$ ) ao longo dos 28 dias de estudo.

Espalhabilidade pode ser definida como a quantidade de trabalho necessária para espalhar uma formulação sobre uma superfície ${ }^{9}$. De acordo com a Figura 1, quando foram comparadas as formulações FSV e FSA, concluiu-se que o valor de "Work of Shear" para a formulação FSA foi estatisticamente significativa e inferior quando comparado com o mesmo parâmetro para a formulação FSV. Desta forma, um valor menor de "work of shear" indica que a formulação tem uma boa espalhabilidade, o que significa uma maior facilidade para se espalhar no cabelo ${ }^{10}$. Desta forma, de acordo com a Figura 1, a formulação contendo óleo de argan tem uma espalha- 
Furthermore, according to Figure 2, during the 28 day study at different temperatures $\left(\mathrm{Tamb}-25^{\circ} \mathrm{C}, \mathrm{T} 37^{\circ} \mathrm{C}\right.$ and $\mathrm{T} 45^{\circ} \mathrm{C}$ ), the spreadability had a better performance for the formulation containing argan oil (FSA) compared to the vehicle formulation (FSV), because its spreadability was lower and had a constant behaviour over the 28 days when compared to vehicle formulation.

On the other hand, during the 14 days (T14) period of analysis, both formulations showed an increase of the "work of shear" parameter. Considering that other studies from our research group ${ }^{11}$ have shown this increase, it could be related to the characteristics of ingredients used in the formulation, including the copolymer diallyldimethylammonium chloride and acrylamide. bilidade melhor (valor mais baixo de "work of shear"), quando comparada com a formulação veículo.

Além disso, de acordo com a Figura 2, durante os 28 dias de estudo, em temperaturas diferentes (Tamb $\left(25^{\circ} \mathrm{C}\right), \mathrm{T}^{\circ} 7^{\circ} \mathrm{C}$ e $\left.\mathrm{T} 45^{\circ} \mathrm{C}\right)$, a espalhabilidade teve um desempenho melhor para a formulação que contém o óleo de argan (FSA) em comparação com a formulação veículo (FSV), porque a sua espalhabilidade foi menor e teve um comportamento constante ao longo dos 28 dias, quando comparado à formulação veículo.

Por outro lado, no período correspondente a 14 dias de análise (T14), ambas as formulações apresentaram um aumento do parâmetro "work of shear". Considerando que outras formulações avaliadas em nossos estudos ${ }^{11}$ tem mostrado este aumento, o mesmo pode estar relacionado à natureza de alguns ingredientes da formulação como o copolímero de cloreto de dialildimetilamônio e acrilamida.

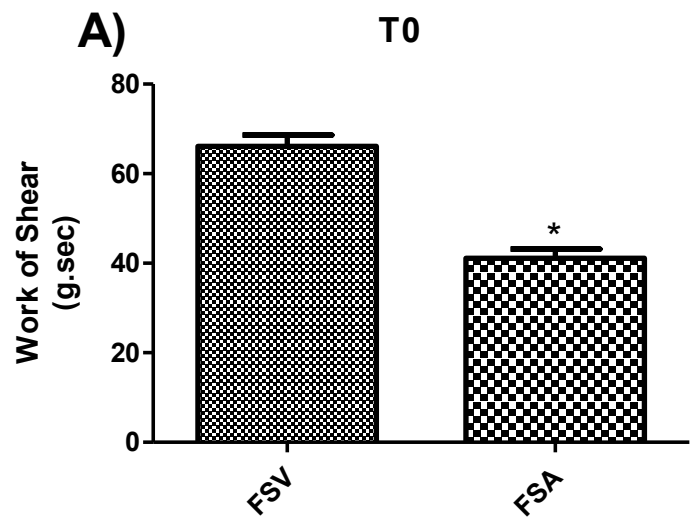

Figure 1/ Figura 1. Spreadability test with the evaluation parameter "Work of Shear" of the formulations under study FSV (vehicle shampoo formulation) and FSA (active shampoo formulation) at T0 (initial measurement) time

Teste Espalhabilidade com a avaliação do parâmetro "Work of Shear" das formulações em estudo FSV (formulação shampoo veículo) e FSA (formulação shampoo ativo) no tempo T0 (medida inicial).

* Statistically different from the comparative formulation. (Student t test, $\mathrm{p}<0.05$ ).

*Estatisticamente diferente da formulação comparada. (Teste T Test, p<0,05). 
A)

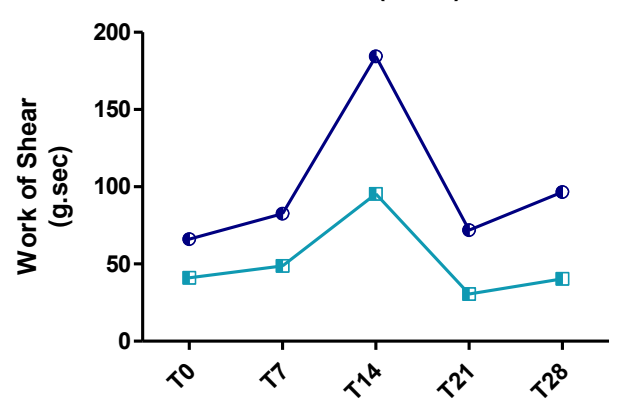

B)

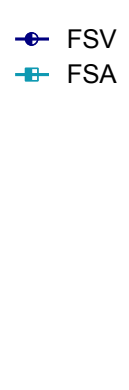

$\mathrm{T} 37^{\circ} \mathrm{C}$

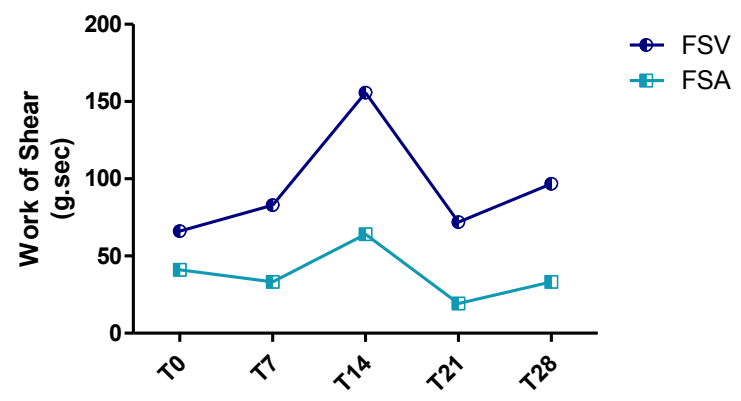

C)

$\mathrm{T} 45^{\circ} \mathrm{C}$

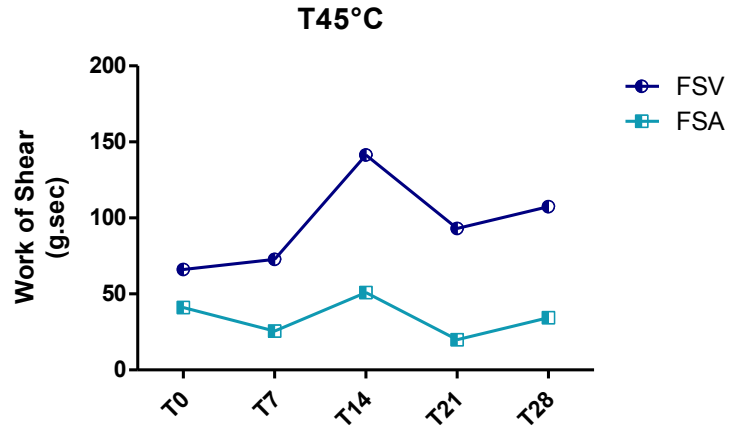

Figure 2/ Figura 2. Spreadability Test with the evaluation parameter "Work of Shear" of the formulations under study FSV (vehicle shampoo formulation) and the FSA (active shampoo formulation) at different temperatures

(Tamb $-25^{\circ} \mathrm{C}, \mathrm{T} 37^{\circ} \mathrm{C}, \mathrm{T} 45^{\circ} \mathrm{C}$ ) over 28 test days.

Teste Espalhabilidade com a avaliação do parâmetro "Work of Shear" das formulações em estudo FSV (formulação shampoo veículo) e FSA (formulação shampoo ativo) em diferentes temperaturas ( $\operatorname{Tamb}\left(25^{\circ} \mathrm{C}\right)$, $\mathrm{T} 37^{\circ} \mathrm{C}$ e $\mathrm{T} 45^{\circ} \mathrm{C}$ ) ao longo de 28 dias de análise.

\section{Texture Profile - Consistency and Viscosity Index}

According to Figure 3, which shows the consistency (A) and the viscosity index (B) for the conditioner formulations studied, containing (FCA) or not argan oil (FCV), it was possible to notice that there were no significant difference in terms of consistency (A) for both formulations. On the other hand, for the viscosity index (B), it was noticed that the formulation containing argan oil (FCA) had a lower value compared to the vehicle formulation (FCV), showing a significant difference between these formulations. This way, the vehicle showed a higher value of viscosity when compared to the formulation with argan oil, indicating that this parameter is worse for FCV when we compared to FCA. Thus, the addition of argan oil contributed for a better performance of the formulation.

Figure 4 shows the consistency (A) and viscosity index (B) for the formulations studied FLV (vehicle leave-in formulation) and FLA (active leave-in formulation). The formulation FLA had a higher consistency value when compared to the value obtained for the FLV formulation, but the difference was not significant. The value obtained for the viscosity index for the formula-

\section{Perfil da Textura - Índice de consistência e viscosidade}

De acordo com a Figura 3 (A), para o teste de consistência, não foram observadas diferenças significativas para este parâmetro para as formulações FCA e FCV quando comparamos as formulações. No entanto, de acordo com o índice de viscosidade (Figura 3B), houve diferença significativa para esse parâmetro quando comparamos as duas formulações estudadas. Assim, o veículo mostrou valores mais altos de viscosidade quando comparado com a formulação contendo óleo de argan, o que indica que para este parâmetro a formulação com óleo de argan apresentou melhores resultados que a formulação veículo. Assim, a adição de óleo de argan contribui para uma melhor performance da formulação.

A Figura 4 mostra os testes de consistência e o índice de viscosidade para as formulações estudadas FLV (formulação leave on veículo) e FLA (formulação leave on ativo). Para o teste de consistência, a formulação contendo o óleo de argan (FLA) obteve um valor maior para o parâmetro consistência quando comparado ao valor obtido para a formulação veículo (FLV), porém essa diferença não foi significativamente diferente. 
tion FLA was lower than the value obtained for the vehicle formulation (FLV), however, this difference was also not significant.
Para o teste de índice de viscosidade, o valor obtido para a formulação contendo o referido ativo (FLA) foi maior quando comparado ao valor obtido para a formulação veículo (FLV), no entanto, essa diferença não foi significativamente diferente.
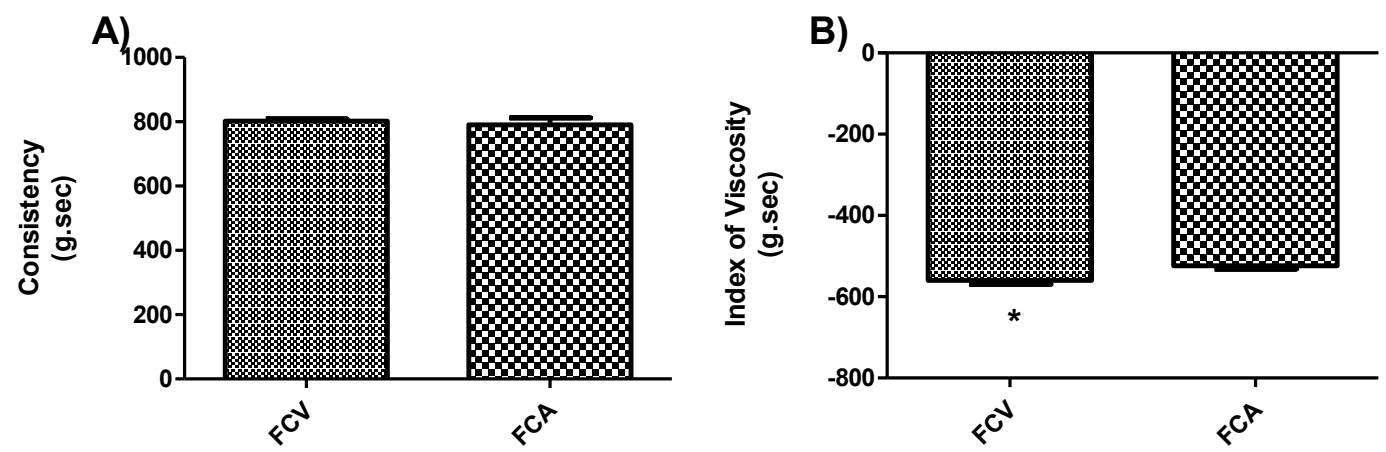

Figure 3/ Figura 3. Consistency (A) and Viscosity Index (B) of the formulations under study FCV (vehicle conditioner formulation) and FCA (active conditioner formulation).

Teste Consistência (A) e Teste Índice de Viscosidade (B) das formulações em estudo FCV (formulação condicionador veículo) e FCA (formulação condicionador ativo).

* Statistically different from the comparative formulation (Student $t$ test, $\mathrm{p}<0.05$ ).

*Estatisticamente diferente da formulação comparada (Teste $T$ Test, $\mathrm{p}<0,05$ ).

A)

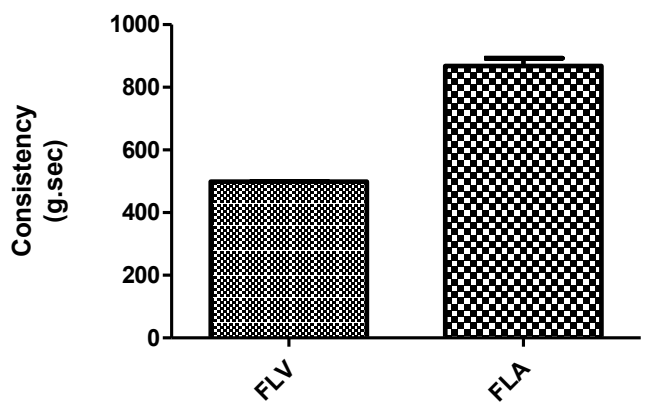

B)

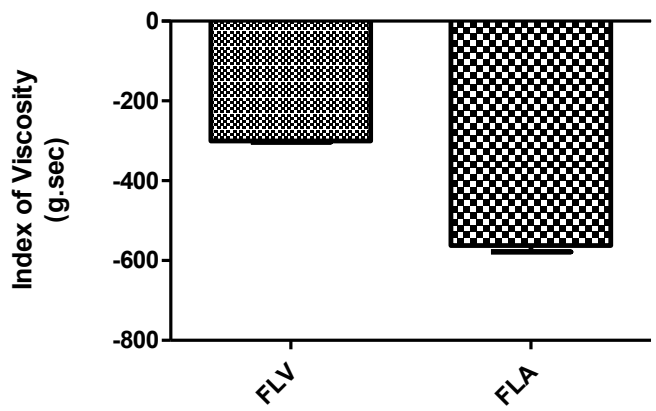

Figure 4/ Figura 4. Consistency (A) and viscosity (B) of the formulations under study FLV Index (vehicle leave-in formulation) and FLA (active leave on formulation). (Student $t$ test, $\mathrm{p}<0.05$ ). Teste de Consistência (A) e Teste de Índice de Viscosidade (B) das formulações em estudo FLV (formulação leave on veículo) e FLA (formulação leave on ativo). (Teste T Test, $\mathrm{p}<0,05$ ). 


\section{Discussion}

The spreadability of a formulation can be defined as the amount of deformation obtained by a necessary force exerted to spread the material over a certain surface ${ }^{12}$.

The spreadability analysis of a cosmetic formulation is a very useful tool for $\mathrm{R} \& \mathrm{D}$, given that through the employed physical principle, the formulator has the conditions to better understand its formulation, i.e., as each raw material may interfere, in a positive or negative way, in the physical and chemical stability of the formulation. A comparative analysis in the different formulations under development will allow, through the information obtained, the formulator to choose the one that has a lower value of "Work of Shear", favoring the choice of a product with nice sensorial values as the unit simulates the conditions of sensory perception of consumer ${ }^{13}$.

Thus, in relation of the shampoo formulations, the addition of argan oil provided an improvement in their performance as there was a reduction in the value of "Work of Shear" when comparing this formulation with the vehicle. Moreover, during the 28 days study at different temperatures $\left(\mathrm{Tamb}-25^{\circ} \mathrm{C}, \mathrm{T} 37^{\circ} \mathrm{C}\right.$ and $\mathrm{T} 45^{\circ} \mathrm{C}$ ), a minor amount of spreadability was noticed in the formulation containing the active as compared to the vehicle formulation.

Thus, a cosmetic formulation with an appropriate spreadability often is the formulation of choice for $\mathrm{R} \& \mathrm{D}$ as this has a nice feel for consumer ${ }^{3}$.

Regarding to the viscosity of a cosmetic formulation, this parameter should have neither an excessively high value, nor too low value. Thus, an intermediate viscosity may be required for a cosmetic formulation because it allows the product to be discharged from the package when the consumer applies a force that it is not excessive but also that the product has a suitable viscosity to be distributed on the hair without being overly fluid.

Finally, according to previous studies ${ }^{14}$, it is known that the addition of vitamins in cosmetic formulations tends to cause instability in their physical properties, such as change in viscosity. Thus, it can be said that due to the rich vitamin composition of argan oil (such as vitamins $\mathrm{A}, \mathrm{D}$ and $\mathrm{E})^{2}$, the viscosity and consistency of the conditioner formulations and leave-in treatments containing argan oil had an expected response profile during evaluation of their stability and texture.

\section{Conclusion}

All developed formulations were stable and the argan oil-based formulations showed better spreadability

\section{Discussão}

A espalhabilidade de uma formulação pode ser definida como a quantidade de deformação obtida por meio de uma força exercida necessária para espalhar esse material sobre uma determinada superfície ${ }^{12}$.

A análise da espalhabilidade de uma formulação cosmética é uma ferramenta de muita utilidade para o P\&D visto que através do seu princípio físico empregado, o formulador tem as condições para entender melhor sua formulação, ou seja, como cada matéria prima pode interferir, seja ela de maneira positiva ou negativa, na estabilidade física e química da formulação, permitindo assim que através das informações obtidas, o formulador possa comparar diferentes formulações em desenvolvimento e escolher aquela que possua um valor de "Work of Shear" menor, favorecendo a escolha de um produto com sensorial agradável já que o aparelho simula as condições de percepção sensorial do consumidor ${ }^{13}$.

Desta forma, com relação às formulações shampoo, a adição de óleo de argan proporcionou uma melhora no seu desempenho visto que houve uma redução no valor de "Work of Shear" quando comparamos a formulação contendo o referido ativo com o veículo. Além disso, ao longo de 28 dias de estudo, em diferentes temperaturas (Tamb $\left(25^{\circ} \mathrm{C}\right), \mathrm{T} 37^{\circ} \mathrm{C}$ e $\left.\mathrm{T} 45^{\circ} \mathrm{C}\right)$, notou-se um valor de espalhabilidade menor para a formulação contendo o ativo quando comparada à formulação veículo. Assim, uma formulação cosmética com uma espalhabilidade adequada costuma ser a formulação de escolha pelo $\mathrm{P} \& \mathrm{D}$ visto que esta possui um sensorial agradável para o consumidor ${ }^{3}$.

Com relação à viscosidade de uma formulação cosmética, este parâmetro não deve ter um valor excessivamente alto e nem um valor muito baixo. Assim, uma viscosidade intermediária pode ser requerida para uma formulação cosmética porque permite que o produto saia da embalagem sem que a força aplicada à mesma, pelo consumidor, seja demasiadamente grande e também, que o produto tenha uma viscosidade adequada para que seja espalhado sobre os cabelos sem ser excessivamente fluido.

Por fim, de acordo com estudos previamente realiza$\operatorname{dos}^{14}$ sabe-se que a adição de vitaminas em formulações cosméticas tende a causar instabilidade em suas propriedades físicas, como por exemplo, a alteração de sua viscosidade. Assim, pode-se dizer que devido à rica composição do óleo de argan em vitaminas como a A, $\mathrm{D}$ e $\mathrm{E}^{2}$, a viscosidade e a consistência das formulações condicionador e leave on contendo o óleo de argan, tiveram um perfil de resposta esperado durante a avaliação de sua estabilidade e textura.

\section{Conclusão}

As formulações foram estáveis e as formulações à base de óleo de argan mostraram melhor espalhabilidade 
when compared with the vehicle. This is a desirable effect as cosmetic formulations which present lower values of work of shear are better accepted by cosmetic sensory panels. In addition, no difference was found between conditioners with or without argan oil in terms of their texture profiles. Nevertheless, the leave-in formulation containing argan oil showed an increase of the consistency when compared to the vehicle. Finally, formulations with argan oil showed a better texture profile, therefore, it is a potential ingredient for use in hair care formulations.

\section{Acknowlegments}

The authors thank CNPq and FAPESP for granting financial support for this study.

\section{Conflict of interest}

The authors declare that there are no financial and/or personal relationships that could be viewed as presenting a potential conflict of interest. quando comparadas com o veículo. Este é um efeito desejável, uma vez que, formulações cosméticas que apresentam menores valores de "Work of Shear" são mais bem aceitas por painéis sensoriais cosméticos. Além disso, não houve diferença entre os condicionadores com ou sem óleo de argan em termos de perfil de textura. No entanto, a formulação leave-on contendo óleo de argan mostrou um aumento da consistência quando comprada com o veículo. Por fim, o óleo de argan melhorou o perfil de textura das formulações sendo, portanto, um potencial ingrediente para aplicação em formulações para os cuidados dos cabelos.

\section{Agradecimentos:}

Os autores agradecem o CNPq e a FAPESP pelo apoio financeiro ao projeto.

\section{Conflito de interesses}

Os autores declaram a inexistência de qualquer tipo de relação financeira ou pessoal que possa representar um potencial conflito de interesses. 


\section{References/ Referências}

1. Guillaume D, Charrouf Z. Argan oil. Alternative Medicine Review 2011; 16: 275-279.

2. Guillaume, D., Charrouf, Z. Argan oil and other argan products: Use in dermocosmetology. Eur. J. Lipid Sci. Technol 2011; 113: 403-408, doi: 10.1002/ejlt.201000417.

3. Estanqueiro M, Conceição J, Amaral MH, Santos D, Silva JB, Lobo JMS. Characterization and stability studies of emulsion systems containing pumice. Brazilian Journal of Pharmaceutical Sciences 2014; 50: 362-369.

4. Tai A, Bianchini R, Jachowicz J. Texture analysis of cosmetic/pharmaceutical raw materials and formulations. Int. J. Cosm. Sci 2014; 36: 291-304.

5. Isaac VLB, Cefali LC, Chiari BG, Oliveira CCLG, Salgado HRN, Corrêa MA. Protocolo para ensaios físico-químicos de estabilidade de fitocosméticos. Rev. Ciênc. Farm. Básica Apl. 2008; 29: 81-96.

6. Stable Micro Systems. The world standard for texture analysis. Reino Unido. $11 \mathrm{p}$

Disponível em: http://www.masontechnology.ie/files/documents/sms1.pdf e http:// www.stablemicrosystems.com.cn/taxtplus. $\mathrm{htm}$

Acessado em: 18/10/2015
7. Estanqueiro M, Conceição J, Amaral MH, Lobo JMS. Use of solid dispersions to increase stability of dithranol in topical formulations. Brazilian Journal of Pharmaceutical Sciences 2014; 50: 583-590.

8. Brenner T, Hayakawa F, Ishihara S, Tanaka Y, Nakauma M, Kohyama K, Achayuthakan P, Funami T, Nishinari K. Linear and nonlinear rheology of mixed polysaccharide gels. Pt. Ii. Extrusion, compression, puncture and extension tests and correlation with sensory evaluation. Journal of Texture Studies 2013; 45: 30-46.

9. Savary G, Grisel M, Picard C. Impact of emollients on the spreading properties of cosmetic products: a combined sensory and instrumental characterization. Colloids and Surfaces B: Biointerfaces 2013; 102: 371378.

10. Estanqueiro M, Conceição J, Amaral MH, Lobo JMS. Characterization, sensorial evaluation and moisturizing efficacy of nanolipidgel formulations. International Journal of Cosmetic Science 2014; 36: 159-166.
11. Gaspar LR, Campos PMBGM . Rheological behavior and the SPF of sunscreens. International Journal of Pharmaceutics 2003; 250: 35-44.

12. Bayarri S, Carbonell I, Costell E. Viscoelasticity and texture of spreadable cheeses with different fat contents at refrigeration and room temperatures. Journal of Dairy Science 2012; 95: 6926-6936.

13. Yadav NP, Srivastava S, Sinha P, Chanda D, Luqman S, Tandon S. Development and evaluation of Aloe vera (L.) Burm. based topical cream formulation. Annals of Phytomedicine 2014, 3: 60-65.

14. Capitani RD, Mercúrio DG, Camargo Junior FB, Campos PMBGM. Stability and Clinical Efficacy of Moisturizing Cosmetic Formulations Containing Vitamins $\mathrm{C}$ and E. Biomedical and Biopharmaceutical Research 2012, 9: $215-224$. 